\title{
利用金纳米晶等离子共振效应实现量子点敏化 太阳能电池的光电流增强
}

\author{
程轫, 吴仰晴, 蒙健, 赵耀龙, 王晓云, 杜祖亮*
}

河南大学特种功能材料重点实验室, 开封 475004

* 联系人, E-mail: zld@ @enu.edu.cn

国家自然科学基金(11274093, 61376061, 61240053)资助

近年来, 量子点敏化太阳能电池 的光电转换效率大幅提升, 得到了研 究者的广泛关注. 量子点敏化太阳能 电池的工作机制和染料敏化太阳能电 池类似, 利用量子点替换传统染料具 有以下优点: (1) 量子点的消光系数高 达 $10^{5} \mathrm{~L} /(\mathrm{mol} \mathrm{cm})$; (2) 量子点的光谱响 应可以通过改变其尺寸而方便地调节; (3) 相较染料而言, 量子点具有较好 的抗水氧性; (4) 量子点具有多激子效 应, 有望发展为高效率的光伏器件.

尽管量子点敏化太阳能电池有诸 多的优点, 但就目前的研究而言, 其 光电转换效率( $6 \%)$ 仍然远远落后于 传统的染料敏化太阳能电池 $(11.5 \%)$, 原因在于目前量子点敏化太阳能电池 的结构还不尽合理. 提高其光电转换 效率需要进一步提高其光吸收效率, 并减小电荷复合. 通常情况下, 量子 点敏化太阳能电池的光阳极采用介孔 颗粒薄膜, 当光生电子在颗粒-颗粒间 通过 “跳跃”的方式在介孔薄膜中传输 时, 在颗粒界面间的复合几率会大幅 增加. 近年来, 研究者利用纳米结构 和纳米材料来提高量子点敏化太阳能 电池的光电转换效率, 一维纳米结构 材料(如纳米棒、纳米线、纳米管等) 被认为可以为光生电子提供直接的传 输通道, 从而可以有效地减小光生电
子在传输过程中的复合损失. 然而, 基于一维纳米结构光阳极的量子点敏 化太阳能电池的性能尚无法和传统介 孔颗粒薄膜相比, 原因在于其较小的 比表面积使得量子点的负载量不足, 从而使整个器件的光吸收效率较低.

本研究通过水热反应制备了 $\mathrm{TiO}_{2}$ 纳米棒阵列, 用柠檬酸钠还原 $\mathrm{HAuCl}_{4} \cdot 3 \mathrm{H}_{2} \mathrm{O}$ 的方法制备了直径约 20 $\mathrm{nm}$ 的金纳米晶. 为研究金纳米晶在量 子点敏化太阳能电池中的光电流增强 效应, 构筑了 $\mathrm{ZnS} / \mathrm{CdSe} / \mathrm{CdS} / \mathrm{TiO}_{2}$ 核 壳结构的纳米线阵列化光阳极. 在该 量子点敏化太阳能电池体系中, 通过 简单地引人金纳米晶, 短路电流从
$7.788 \mathrm{~mA} / \mathrm{cm}^{2}$ 增加到 $8.574 \mathrm{~mA} / \mathrm{cm}^{2}$, 增强了约 $10 \%$; 整个器件的光电转换 效率从 $1.66 \%$ 增加到 $1.73 \%$, 增强了约 $4.2 \%$. 这种增强效应主要由金纳米晶 受到激发后电子向 $\mathrm{ZnS} / \mathrm{CdSe} / \mathrm{CdS} / \mathrm{TiO}_{2}$ 光阳极注人所致. 为证实此结论, 我 们通过原位反应使所制备的金纳米晶 与 $\mathrm{TiO}_{2}$ 纳米棒阵列复合, 构筑了单一 的 $\mathrm{Au} / \mathrm{TiO}_{2}$ 复合体系。在可见光照射下, 能够清楚地观察到光电流产生现象, 而单一的 $\mathrm{TiO}_{2}$ 在可见光照射下, 并不 能产生光电流, 实验结果如图 1(a)所 示, 该实验进一步证实了我们的结论. 光照情况下, $\mathrm{Au}-\mathrm{TiO}_{2}$ 界面处等离子共 振激发的电荷转移过程如图1(b)所示.
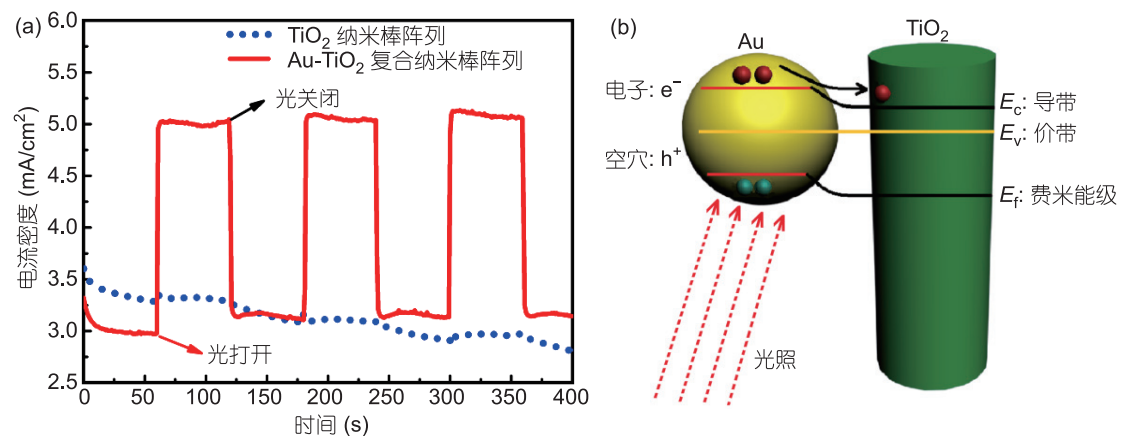

图 1 (网络版彩色)(a) 可见光开关照射下 $\mathrm{TiO}_{2}$ 和 $\mathrm{Au}-\mathrm{TiO}_{2}$ 纳米棒阵列的电流密度-时间图; (b) $\mathrm{Au}-\mathrm{TiO}_{2}$ 界面处光照下等离子共振激发的电荷转移过程示意图 